\title{
Valmiuslaki, demokratia ja perusoikeudet
}

\author{
Kaarlo Tuori
}

En usko poliittiseen työnjakoon, jossa minä (juristit) työskentelen "oikeusvaltiollisten periaatteiden" puolesta ja laajempi kritiikki jää sosiologeille ja valtiotieteilijöille. En ole komiteajäsenyyksieni myötä hyväksynyt tehtävänasettelua ja siihen implisiittisesti sisältyviä valtion "turvallisuustarpeita". Sen sijaan uskon kyllä, että oikeusvaltiollisiin periaatteisiin vetoamisella on myös niin sanotussa kriittisessä keskustelussa oma sijansa. Samoin uskon, että kannattaa myös harjoittaa näihin periaatteisiin nojautuvaa komiteakritiikkiä. En usko, että kritiikin sitoutuminen kansalaisoikeuksiin ja niitä loukkaavaan repressiiviseen valtaan "syö" pehmeiden integraatiokoneistojen poliittista merkitystä. Siksi: seuraavassa annos tyylipuhdasta komiteakritiikkiä.

Poikkeusolojen viranomaisvaltuuksia sääntelevän valmiuslainsäädännön valmistelussa saavutettiin jälleen uusi vaihe, kun oikeusministeriön asettama työryhmä luovutti tämän vuoden maaliskuun lopulla mietintönsä.

Tuoreimmankin valmiuslakiesityksen yhteydessä ajankohtaistuvat hätätilaoikeuden yleiset ongelmat. Tarkoitan hätätilaoikeudella kokoavasti valtioelinten poikkeusoloissa käyttämää poikkeuksellista toimivaltaa, jota justifioidaan tavoitteella voittaa poikkeusolot, palauttaa normaalitila. Poikkeuksellista toimivaltaa käyttävät yleensä valtion toimeenpanoelimet, ja toimivalta sisältää yleensä myös oikeuden puuttua kansalaisten muuten perustuslailla suojattuihin oikeuksiin.

Oikeusperustansa nojalla hätätilaoikeutta on kahta tyyppiä: valtiosääntöistä ja ulkovaltiosääntöistä. Näistä edellinen perustuu valtiosäännön mukaisessa järjestyksessä luotuihin valtuuksiin. Sen sijaan ulkovaltiosääntöiseen hätätilaoikeuteen turvauduttaessa viranomaisen poikkeusaikojen poikkeustoimenpiteillä ei ole toimivaltaperustaa valtiosäännön mukaisessa järjestyksessä hyväksytyissä säädöksissä: viranomaiset ryhtyvät kriisin voittamiseksi tarpeellisiksi katsomiinsa toimenpiteisiin eräänlaisen kirjoitetun oikeusjärjestyksen yläpuolisen oikeusperiaatteen nojalla. Tällaiseksi oikeusperiaatteeksi saatetaan esittää valtion yleinen etu tai valtion itsepuolustusoikeus tms.

Ulkovaltiosääntöisen hätätilaoikeuden mahdollisuuteen on meillä yleensä suhtauduttu torjuvasti $\mathrm{mm}$. oikeusvaltiolliseen hallinnon lainalaisuusperiaatteeseen viitaten: on katsottu, että viranomaisilla tulee myös poikkeusoloissa olla toimenpiteilleen toimivaltaperusta kirjoitetun oikeuden säännöksissä. Tästä näkökohdasta onkin syytä pitää kiinni: kirjoittamattomien oikeusperiaatteiden epämääräisyyden vuoksi niihin tukeutuminen kriisitilanteessa merkitsee vakavaa vaaraa niin demokraattiselle järjestelmälle kuin kansalaisten oikeusturvalle, ennen muuta perusoikeuksien suojalle. Tästä syystä en pidä toivottavana, että edes lakien esitöissä viitattaisiin tällaisen hätätilaoikeuden mahdollisuuteen. Tällainen viittaus kuitenkin sisältyy myös valmiuslakityöryhmän hallituksen esityksen muotoon kirjoitettuun mietintöön: "Ennalta säädetty poikkeusoloissa sovellettava lainsäädäntö ... estää sen demokraattisen hallitsemistavan kannalta epätoivottavan vaihtoehdon, että hallitusvalta säännösten puuttuessa toimisi poikkeusoloissa kirjoitetun oikeusjärjestyksen vastaisesti ja vasta jälkeenpäin pyrkisi hankkimaan toiminnalleen eduskunnan hyväksymisen". Tällaiset lainvalmisteluasiakirjoihin kirjoitetut lausumat saattavat antaa aiheen tulkintaan, jonka mukaan oikeusjärjestyksemme sallisi ulkovaltiosääntöiseen hätätilaoikeuteen turvautumisen.

Oikeusministeriön työryhmän esitykses- 
sä laiksi yhteiskunnan toimintojen turvaamisesta poikkeusoloissa on kysymys valtiosääntöisen hätätilaoikeuden piiriin kuuluvasta hankkeesta. Oikeusvaltiollisten periaatteiden puolesta työskentelevällä fragmentaarisella ja teoreettisemman aineiston hyväksikäytön laiminlyövällä komiteakritiikillä on kaksi kriteeriä (joiden kummankaan kohtaloa en haluaisi jättää vain naurureaktion varaan) tällaisten hankkeiden arvioimiseksi:

- edustuksellisten elinten — meillä eduskunnan ja kunnanvaltuustojen - asema

- kansalaisten oikeuksien, erityisesti perustuslailla turvattujen oikeuksien suoja.

Ensimmäisen kriteerin kannalta keskeinen kysymys on, miten turvataan eduskunnan vaikutusvalta toisaalta poikkeusvaltuuksien käytön aloittamisessa ja toisaalta itse poikkeusvaltuuksien soveltamisessa. Ehdotuksen mukaan poikkeusolojen poikkeuksellista toimivaltaa, joka normaalioloissa kuuluu valtiosäännön mukaiselle lainsäätäjälle, käyttäisi valtioneuvosto. Valtuuksien käytön aloittamisesta sen sijaan päätettäisiin presidentin enintään vuodeksi kerrallaan antamalla asetuksella, joka olisi vielä saatettava eduskunnan hyväksyttäväksi ennen kuin valtioneuvosto voisi ryhtyä soveltamaan lain sille perustamaa toimivaltaa. Ns. kiiretilanteissa - milloin pääsääntöistä menettelyä ei ole mahdollista noudattaa vaarantamatta merkittävästi lain tarkoituksen saavuttamista - enintään kolmeksi kuukaudeksi annettavalla asetuksella voitaisiin kuitenkin säätää, että valtioneuvosto saa käyttää toimivaltuuksia välittömästi. Tässäkin tapauksessa asetus olisi kahden viikon kuluessa sen antamisesta saatettava eduskunnan käsiteltäväksi.

Eduskunnalla olisi myös lain nojalla annettuja valtioneuvoston päätöksiä koskeva jälkikontrollioikeus. Poikkeuksellisten toi- mivaltuuksien käyttämistä koskevat valtioneuvoston päätökset olisi näet heti annettava eduskunnan käsiteltäväksi ja kumottava, jos eduskunta niin päättää.

Työryhmä on yllättävän lyhyesti sivuuttanut muut mahdollisuudet eduskunnan aseman turvaamiseksi. Ensinnäkin on hyvinkin ajateltavissa, että ensisijaisesti tarvittavat poikkeusaikojen säännökset antaisi eduskunta itse. Tällainen vaihtoehtohan, jota mietinnössä ei edes mainita, on omaksuttu niin sanottuun valtiosääntöpakettiin liittyvässä uudessa valtiopäiväjärjestyksen 67a §:ssä. Tämän säännöksen tarkoituksena on lepäämisjättämismahdollisuuden kieltämisellä ja määräenemmistövaatimusta lieventämällä mahdollistaa, että eduskunta itse voisi päättää niistä taloudellisista säännöstelytoimenpiteistä, jotka ovat välttämättömiä kansantaloutta uhkaavan vakavan häiriön lieventämiseksi. Tämän säännöksen esikuvaa seurattaessa pääsääntöisestä eduskuntatiestä luovuttaisiin vasta silloin, jos se kulloisessakin kriisitilanteessa osoittautuisi todella mahdottomaksi noudattaa.

Eduskunnan asemaa voitaisiin vahvistaa myös toimeenpanoelimille kuuluvien valtuuksien käytön aloittamisessa. Niinpä voidaan ajatella, että tällöinkin ensisijainen menettely olisi se, että eduskunta esimerkiksi lailla toteaisi poikkeusvaltuuksia edellyttävän poikkeustilan olevan käsillä. Asetustiehen turvauduttaisiin vain, jos tällaista menettelyä akuutissa kriisissä ei voitaisi soveltaa. Tällainenkaan menettely ei ole kansainvälisesti katsoen uusi: esimerkiksi Ranskan piiritystilalainsäädännön mukainen pääsääntö on, että piiritystila julistetaan lailla.

Eduskunnan aseman kannalta keskeisiä ovat myös määräajat, joita toimeenpanoelinten poikkeusvaltuuksien käytölle asetetaan. Poikkeusvaltuuksien käyttämiseen oi- 
keuttavan asetuksen voimassaololle ehdotettu vuoden määräaika pääsääntönä ja kolmen kuukauden määräaika kiiretilanteissa ovat pitkiä. Jos poikkeuksellisten toimivaltajärjestelyjen perustana on se, että eduskunta on menettänyt normaalin toimintakykynsä, voidaan olettaa, että yleensä toimintakyky palautuu ehdotettuja enimmäismääräaikoja lyhyemmässä ajassa. Pitkien määräaikojen tarvetta nykyoloissa vähentää myös se, että eduskunta on nykyisin koolla käytännöllisesti katsoen koko vuoden. Todettakoon vertailun vuoksi, että esimerkiksi Englannin hätätilalain Emergency Powers Act - mukaan hätätilajulistus on voimassa ainoastaan kuukauden kerrallaan.

Kansainväliset kokemukset puhuvat sen puolesta, että jo säännöstasolla on pyrittävä estämään poikkeusvaltuuksien väärinkäytön mahdollisuus. Eräs mahdollinen väärinkäytöstilanne liittyy ylimpien valtioelinten poliittiseen ristiriitaan, johon haetaan ratkaisua hätätilavaltuuksista: ylimmät toimeenpanoelimet käyttävät poikkeusvaltuuksia ikään kuin taisteluaseena parlamenttia vastaan. Tässä yhteydessä riittänee viittaus Weimarin tasavallan viime vuosiin. Tällaisen väärinkäytön estämiseksi esimerkiksi Weimarin tasavallan alkuvuosina säädetyissä valtuuslaeissa oli tapana sitoa valtuuksien voimassaolo kulloinkin istuvan hallituksen kokoonpanoon: mikäli hallitus tai sen puoluepoliittinen koostumus muuttui, myös valtuuksien voimassaolo päättyi. Ranskan V tasavallassa, jonka valtiosääntö niin ikään korostaa presidentin asemaa, presidentin poikkeusvaltuuksia koskevassa valtiosääntöartiklassa on puolestaan kielletty parlamentin hajotus valtuuksien soveltamisaikana. Myöskään tämän tyyppisiä valtuuksien väärinkäytön pidäkkeitä ja eduskunnan asemaa turvaavia järjestelyjä työryhmän mietinnössä ei ole pohdittu.

Kansalaisten perusoikeuksien ja oikeusturvan kannalta on tärkeää, että poikkeusvaltuudet on määritelty sekä soveltamisedellytyksiltään että sisällöltään mahdollisimman täsmällisesti. Kulloinkin käytettävissä olevat valtuudet tulisi myös mitoittaa käsillä olevan kriisin luonteen ja vakavuusasteen mukaisesti. Tässä suhteessa työryhmän omaksuma pakettiratkaisu, jossa kaikki luonteeltaan hyvinkin eri tyyppisiä kriisejä varten tarkoitetut poikkeusvaltuudet on sijoitettu samaan lakiin, on altis kritiikille. Lakiehdotuksen poikkeusolojen luetteloonhan kuuluu sekä sotilaallisia kriisejä että puhtaita siviilikriisejä, ja poikkeusolojen määritelmät myös sisältävät eräitä väljiä ja tulkinnanvaraisia ilmauksia. Myönteistä ehdotuksessa kyllä on, että valtuuksien soveltamisen mahdollistavassa asetuksessa olisi yksilöitävä käytettävissä olevat valtuudet samoin kuin niiden alueellinen soveltamisala ja että valtioneuvosto saataisiin oikeuttaa käyttämään vain sellaisia toimivaltuuksia, jotka kulloinkin ovat välttämättömiä lain tarkoituksen saavuttamiseksi.

Sen estämiseksi, että poikkeusvaltuuksia ei käytetä kuin sen tyyppisissä kriiseissä, joihin ne on tarkoitettu, jo itse laissa tulisi eri valtuuksien osalta nimenomaisesti mainita ne poikkeusolot, joissa niitä voidaan soveltaa. Toinen mahdollisuus olisi purkaa paketti eli palata kriisityypeittäin ja valtuuksittain eriytettyjen erillisten, perustuslain säätämisjärjestyksessä käsiteltävien valmiuslakien linjalle. Tätä linjaa noudatettaessa eduskunnalla myös olisi pakettiratkaisua huomattavasti paremmat mahdollisuudet arvioida jo lakeja säädettäessä eri poikkeusvaltuuksien välttämättömyyttä.

Lakiehdotuksen 9 §:ään on otettu yleisiä säännöksiä, joiden tarkoituksena on suojata kansalaisten perustuslaissa taattuja oi- 
keuksia myös poikkeusvaltuuksia käytettäessä. Tässä pykälässä on $\mathrm{mm}$. lueteltu ne hallitusmuodon II luvun mukaiset perusoikeudet, joita valmiuslakiin perustuen ei saada rajoittaa muulloin kuin Suomeen kohdistuvan aseellisen hyökkäyksen ja sodan aikana. Tällaisen säännöksen ongelmana on se, että sitä saatetaan käyttää vastakohtaispäätelmän tukena: säännös voidaan lukea siten, että se oikeuttaisi lakia sovellettaessa rajoittamaan muita kuin siinä nimenomaisesti mainittuja oikeuksia - esimerkiksi vaikkapa vaali- ja äänioikeutta ja että se valtuuttaisi nimenomaisesti mainittujenkin oikeuksien - esimerkiksi hallitusmuodon 10 §:n tarkoittamien poliittisten perusoikeuksien - rajoittamiseen sodan tai aseellisen hyökkäyksen oloissa. Jos tällainen lukutapa omaksutaan, säännöksen voitaisiin katsoa oikeuttavan tulkitsemaan vaikkapa säännöksiä tavaroiden takavarikoinnista tai tuonti- ja vientikielloista taikka rakennusten luovuttamisvelvollisuudesta siten, että niiden nojalla voidaan rajoittaa esimerkiksi paino- ja kokoontumis- sekä uskonnonharjoittamisvapautta.

Valtuuksien sisällön täsmällisyysvaatimuksen kannalta monet ehdotetut säännökset jättävät runsaasti tarkistamisen va- raa. Tällaisia ovat esimerkiksi: työvelvollisuussäännös, joka ulottaa tämän velvollisuuden "lain tarkoituksen saavuttamiseksi tarpeelliseen työhön"; säännös, joka mahdollistaa hallintoviranomaisten toimivaltaja toimialasuhteiden muuttamisen; kunnallisvaalien ja kunnanvaltuuston päätösvallan siirtämiseen oikeuttavat säännökset; tavaroiden takavarikointia ja pakkoluovutusta koskeva yleissäännös; yleissäännös "asianomaisen viranomaisen" tarkastusoikeudesta; sekä yleissäännös, joka valtuuttaa "asianomaiset viranomaiset" antamaan salassapitomääräyksiä.

Vastaukseksi esittämiini kommentteihin ei riitä viittaus tasavallan presidentin, valtioneuvoston ja alempien viranomaisten ansaitsemaan luottamukseen. Mikäli luottamus viranomaisten harkintakykyyn nostettaisiin tärkeimmäksi kriteeriksi, jolla viranomaisille kansalaisiin kohdistuvaa toimivaltaa perustavaa lainsäädäntöä arvioidaan, voisimme jättää hyvästit niin perusoikeussäännöksille kuin niitä täydentäville oikeusvaltiollisille oikeusturvamekanismeillekin. Koko oikeusvaltiollinen ajattelu perustuu eräänlaiseen terveeseen epäluottamukseen julkisen vallan käyttäjiä kohtaan. 